\title{
A DIVALENT CATION-DEPENDENT ATP-ASE IN HUMAN SPERMATOZOA
}

\author{
A. ABLA, A. MROUEH ANd I. F. DURR \\ Departments of Biochemistry and Obstetrics-Gynecology, \\ American University of Beirut, Beirut, Lebanon
}

(Received 10th September 1973)

Evidence is presented for $\mathrm{a}\left(\mathrm{Ca}^{++}+\mathrm{Mg}^{++}\right)$-dependent ATPase in the spermatozoa of man. The enzyme appears to be localized in the sperm tail, and is inhibited by $2: 4$-dinitrophenol, but not by ouabain. The $\left(\mathrm{Na}^{+}+\mathrm{K}^{+}\right)$-dependent ATPase previously reported (Durr, Abla \& Mroueh, 1972) is inhibited by ouabain, but not by 2:4-dinitrophenol (DNP).

Fresh semen was collected and processed as previously described (Durr et al., 1972), using a tris-HCl buffer $\mathrm{pH} 7$ as the wash fluid. Aliquots (3 ml) of washed sperm suspensions were sonicated in a Branson sonifer (Model 3125) for $3 \mathrm{~min}$ at $0^{\circ} \mathrm{C}$ using $10 \mathrm{~A}$ d.c. (Harrison, 1971). The homogenate was fractionated by centrifuging at $0^{\circ} \mathrm{C}$ for $10 \mathrm{~min}$ at $121 \mathrm{~g}$, when tail fragments remained in the supernatant and heads were isolated in the pellet.

The ATPase was assayed by determining the radioactivity in inorganic phosphate released from $\left[\gamma_{-}{ }^{32} \mathrm{P}\right] \mathrm{ATP}$. The method used was a modification of that described by Crane \& Lipmann (1953). The incubation was terminated by immersing the tube in a boiling water bath for $1 \mathrm{~min}$, and the coagulated protein was removed by centrifugation. The supernatant $(1 \mathrm{ml})$ was mixed with $100 \mathrm{mg}$ of activated charcoal and stirred for $15 \mathrm{~min}$ (the activated charcoal was initially mixed with $\mathrm{NaH}_{2} \mathrm{PO}_{4}(4: 1 \mathrm{w} / \mathrm{w})$ to prevent non-specific adsorption of ${ }^{32} \mathrm{P}$ ). The charcoal was removed by centrifugation and the supernatant was filtered through a Whatman No. 2 filter paper. An aliquot was plated, dried and counted. Control experiments showed no contamination with radioactive ATP.

It is well known that in most cell species several ATPases are normally found, each dependent on the presence of different cations. To investigate and differentiate between some of these ATPases in human spermatozoa, the rate of ATP hydrolysis by washed intact spermatozoa was measured in the presence of various cations. At least two ATPases could be demonstrated. Results presented in Table 1 show that ATPase activity was minimal when cations were either excluded or added separately. Addition of $\mathrm{Ca}^{++}$or $\left(\mathrm{Na}^{+}+\mathrm{K}^{+}\right)$alone caused about $70 \%$ and $100 \%$ stimulation in the presence of $\mathrm{Mg}^{++}$, while an additive effect was observed when both the monovalent and divalent cations were present together. Ouabain abolished the stimulation by $\left(\mathrm{Na}^{+}+\mathrm{K}^{+}\right)$but not that by $\mathrm{Ca}^{++}$. Further evidence for the presence of two ATPases was provided 
Table 1. Effect of cations and ouabain on ATPase activity in human spermatozoa

\begin{tabular}{|c|c|}
\hline Cations added & ${ }^{32} P$ formed ( $\left.n m o l\right)$ \\
\hline $\begin{array}{l}\text { None } \\
\mathrm{Mg}^{++} \\
\left(\mathrm{Na}^{+}+\mathrm{K}^{+}\right) \\
\mathrm{Ca}^{++} \\
\mathrm{Mg}^{++}+\mathrm{Ca}^{++} \\
\mathrm{Mg}^{++}+\mathrm{Ca}^{++}+\text {ouabain } \\
\mathrm{Mg}^{++}+\left(\mathrm{Na}^{+}+\mathrm{K}^{+}\right) \\
\mathrm{Mg}^{++}+\left(\mathrm{Na}^{+}+\mathrm{K}^{+}\right)+\text {ouabain } \\
\mathrm{Mg}^{++}+\left(\mathrm{Na}^{+}+\mathrm{K}^{+}\right)+\mathrm{Ca}^{++} \\
\mathrm{Mg}^{++}+\left(\mathrm{Na}^{+}+\mathrm{K}^{+}\right)+\mathrm{Ca}^{++}+\text {ouabain } \\
\text { Inactivated spermatozoa }+ \text { all cations }\end{array}$ & $\begin{array}{r}15 \cdot 6 \\
17 \cdot 3 \\
18 \cdot 4 \\
13 \cdot 7 \\
29 \cdot 0 \\
27 \cdot 8 \\
36 \cdot 0 \\
20 \cdot 0 \\
48 \cdot 5 \\
26 \cdot 2 \\
2 \cdot 6\end{array}$ \\
\hline
\end{tabular}

The incubation mixture contained $1 \times 10^{8}$ intact spermatozoa, $100 \mathrm{nmol}\left[\gamma_{-32} \mathrm{P}\right]$ ATP $\left(34 \times 10^{5} \mathrm{ct} / \mathrm{min}\right)$, and 700 $\mu \mathrm{mol}$ tris-HCl buffer, $\mathrm{pH} 7$, in a final volume of $1 \mathrm{ml}$. The incubation was at $37^{\circ} \mathrm{C}$ for $30 \mathrm{~min}$ with shaking. Additions were as indicated to give a final concentration of $100 \mathrm{mM}$ $\mathrm{NaCl}, 3 \mathrm{~mm}$ each of $\mathrm{KCl}$ and $\mathrm{MgCl}_{2}, 0.1 \mathrm{mM} \mathrm{CaCl}_{2}$, and $0.1 \mathrm{~mm}$ ouabain.

Table 2. Effect of 2,4-dinitrophenol (DNP) on the activity of monovalent and divalent cation-dependent ATPases in human spermatozoa

\begin{tabular}{l|c}
\hline \multicolumn{1}{c|}{ Additions } & ${ }^{32}$ P formed $(\mathrm{nmol})$ \\
\hline None & $19 \cdot 3$ \\
$\left(\mathrm{Ca}^{++}+\mathrm{Mg}^{++}\right)$ & $36 \cdot 5$ \\
$\left(\mathrm{Ca}^{++}+\mathrm{Mg}^{++}\right)+\mathrm{DNP}$ & $20 \cdot 0$ \\
$\mathrm{Mg}^{++}+\left(\mathrm{Na}^{+}+\mathrm{K}^{+}\right)$ & $45 \cdot 6$ \\
$\mathrm{Mg}^{++}+\left(\mathrm{Na}^{+}+\mathrm{K}^{+}\right)+\mathrm{DNP}$ & $39 \cdot 7$ \\
\hline
\end{tabular}

The conditions of incubation were as in Table 1. The final concentration of DNP was $3 \mathrm{~mm}$.

Table 3. Activity of divalent cationdependent ATPase in different fractions of human spermatozoa

\begin{tabular}{l|c}
\hline \multicolumn{1}{c|}{ Preparation } & ${ }^{32}$ P formed (nmol) \\
\hline Intact spermatozoa & $25 \cdot 4$ \\
Tails & $27 \cdot 8$ \\
Heads & $5 \cdot 3$ \\
\hline
\end{tabular}

The incubation mixture contained $1 \times 10^{8}$ intact spermatozoa or the equivalent of tails or heads, $100 \mathrm{nmol}\left[\gamma_{-}{ }^{32} \mathrm{P}\right] \mathrm{ATP}\left(2 \cdot 1 \times 10^{5} \mathrm{ct} / \mathrm{min}\right), 700$ $\mu \mathrm{mol}$ tris-HCl buffer, $\mathrm{pH} 7,3 \mu \mathrm{mol} \mathrm{MgCl}_{2}$, and $0.1 \mu \mathrm{mol} \mathrm{CaCl}_{2}$ in a final volume of $1 \mathrm{ml}$. The incubation was for $30 \mathrm{~min}$ at $37^{\circ} \mathrm{C}$ with shaking. 
by the inhibiting effect of DNP. Wins \& Schoffeniels (1966) reported that DNP specifically inhibited the $\left(\mathrm{Ca}^{++}+\mathrm{Mg}^{++}\right)$- but not the $\left(\mathrm{Na}^{+}+\mathrm{K}^{+}\right)$-dependent ATPase of red blood cell ghosts. Results presented in Table 2 indicate that DNP exerts a similar effect on human sperm ATPases. When the activity of the $\left(\mathrm{Ca}^{++}+\mathrm{Mg}^{++}\right)$ATPase was determined over a range of concentrations $(0 \cdot 1$ to $12 \mathrm{~mm})$ of $\mathrm{Ca}^{++}$and $\mathrm{Mg}^{++}$, either separately or together, maximal activity occurred in the presence of both at a concentration of $1 \mathrm{mM} \mathrm{Ca}^{++}$and $6 \mathrm{~mm} \mathrm{Mg}^{++}$.

The location of the divalent cation-dependent ATPase was investigated by assaying its activity in different fractions of sonicated spermatozoa and comparing it to that of intact spermatozoa in the same sample. Results presented in Table 3 show that the activity of the enzyme in washed intact spermatozoa could be accounted for in the tail-containing fraction. When the experiment was repeated, assay of the $\left(\mathrm{Na}^{+}+\mathrm{K}^{+}\right)$-dependent ATPase showed that the tail-fraction and the head-fraction contained $75 \%$ and $25 \%$, respectively, of the activity of the intact cells.

The use of either intact or sonicated spermatozoa limits the quantitative value of the reported results. Intact cells have restricted permeability to exogenous ATP and disruption may have inactivated some ATPases in sonicated cells.

We thank Dr Khalidi for making the modified ATP assay available to us. $\mathrm{Mr}$ Abla was supported, in part, by a Ford Foundation grant, AUB Population Studies.

\section{REFERENGES}

Crane, R. \& Lipmann, F. (1953) The effect of arsenate on aerobic phosphorylation. F. biol. Chem. 201, 235.

Durr, I. F., Abla, A. \& Mroueh, A. (1972) ATPase of human spermatozoa. F. Reprod. Fert. 31, 313.

HARRISON, R. A. P. (1971) Glycolytic enzymes in mammalian spermatozoa. Biochem. 7. 124, 741.

Wins, P. \& Schofreniels, E. (1966) Studies on red-cell ghost ATPase. Biochim. biophys. Acta, 120, 341 . 